\title{
Protic Ionic Liquid-Derived Coordination Polymer Glass for Anhydrous Proton Conductor with Moldability
}

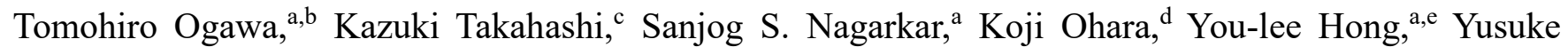
Nishiyama ${ }^{\mathrm{e}, \mathrm{f}}$ and Satoshi Horike*,a,b,c,d

a AIST-Kyoto University Chemical Energy Materials Open Innovation Laboratory (ChEM-OIL), National Institute of Advanced Industrial Science and Technology (AIST), Yoshida-Honmachi, Sakyo-ku, Kyoto 606-8501, Japan

${ }^{\mathrm{b}}$ Institute for Integrated Cell-Material Sciences, Institute for Advanced Study, Kyoto University, Yoshida-Honmachi, Sakyo-ku, Kyoto 606-8501, Japan

c Advanced Research and Innovation Center, DENSO CORPORATION, 500-1 Minamiyama, Komenoki-cho, Nisshin, Aichi 470-0111, Japan

${ }^{\mathrm{d}}$ Diffraction and Scattering Division, Center for Synchrotron Radiation Research, Japan Synchrotron Radiation Research Institute (JASRI), Kouto, Sayo, Hyogo 679-5198, Japan

${ }^{\text {e }}$ RIKEN-JEOL Collaboration Center, Yokohama, Kanagawa 230-0045, Japan

${ }_{\mathrm{f}}^{\mathrm{f}}$ NMR Science and Development Division, RIKEN SPring-8 Center, Yokohama, Kanagawa 230-0045, Japan, and JEOL RESONANCE Inc., Akishima, Tokyo 196-8558, Japan

${ }^{g}$ Department of Synthetic Chemistry and Biological Chemistry, Graduate School of Engineering, Kyoto University, Katsura, Nishikyo-ku, Kyoto 615-8510, Japan

${ }^{\mathrm{h}}$ Department of Materials Science and Engineering, School of Molecular Science and Engineering, Vidyasirimedhi Institute of Science and Technology, Rayong, 21210, Thailand

Correspondence and requests for materials should be addressed to S.H. (*horike@icems.kyoto-u.ac.jp) 


\section{ABSTRACT}

Anhydrous proton conductors working at intermediate temperature are desired for fuel cell-based applications. It remains challenging to design the materials showing high proton conductivity and mechanical moldability to form stable membrane under the anhydrous condition. Herein, we focused on coordination polymer (CP) glass as a hybrid, soft electrolyte to meet these criteria. We applied a protic ionic liquid of which components work also as bridging ligand to construct $\mathrm{CP}$ structure with $\mathrm{Zn}^{2+}$ ions. The structural analysis of the $\mathrm{CP}$ glass reveals that network formation results in enhancement of the properties of proton conductivity and viscoelasticity. The CP glass features a high anhydrous proton conductivity $\left(\sigma=13.3 \mathrm{mS} \mathrm{cm}^{-1}\right.$ at $\left.120^{\circ} \mathrm{C}\right)$ and high transport number of proton (0.94). Fabricated fuel cell with this $\mathrm{CP}$ glass membrane exhibits a high open circuit voltage $(0.96 \mathrm{~V})$ and a power density $(0.15 \mathrm{~W}$ $\mathrm{cm}^{-2}$ ) under dry conditions at $120^{\circ} \mathrm{C}$.

\section{INTRODUCTION}

Proton conductive materials are important components of various electrochemical devices. ${ }^{1-4}$ One of significant devices is the fuel cell, and the anhydrous proton conductors as electrolyte working at $120-200{ }^{\circ} \mathrm{C}$ have long been strongly demanded. ${ }^{3,5,6}$ As a solid electrolyte, not only the high ion conductivity but materials handleabilities for membrane fabrication is also required. ${ }^{7,8}$ In the past decade, a number of studies on the proton conductivity of coordination polymers (CPs) and metal-organic frameworks (MOFs) were reported. ${ }^{9}, 10$ The crystalline CP/MOFs have advantages for high proton conductivity because of their tailorable pore interior and accommodation ability of guest molecules. However, they are intrinsically non-moldable because of crystalline nature, and the grain boundary in the membrane causes the enhancement of resistance and gas leaking. More recently, liquid and glassy states of $\mathrm{CP} / \mathrm{MOF}$ have received attention as moldable amorphous materials. ${ }^{11-18}$ The phase transitions from crystals to liquids and glasses of $\mathrm{CP} / \mathrm{MOFs}$ provide a grain boundary-free monolith, which is one promising properties for solid electrolyte. ${ }^{12,19-21}$ In spite of their potentials, there is a limited amount of reports on protonconductive CP/MOFs glass, and no example to meet criteria for both sufficient proton conductivity (above $10 \mathrm{mS}$ $\mathrm{cm}^{-1}$ ) under anhydrous condition and the materials moldability to fabricate membrane toward fuel cell demonstration. ${ }^{18,19,22}$

Among the reported materials besides $\mathrm{CP} / \mathrm{MOFs}$, the representative anhydrous proton conductors are protic ionic liquids. ${ }^{23,24}$ They are a subset of ionic liquids synthesized from Brønsted acids and bases. A number of combination of acid and base to create protic ionic liquids were reported, and the optimal compositions display high proton conductivity (reaching $50 \mathrm{mS} \mathrm{cm}^{-1}$ at $120^{\circ} \mathrm{C}$ ) and chemical and/or thermal stabilities. ${ }^{25}$ Protic ionic liquids exhibiting high proton conductivity typically show low viscosity, which is known as Walden's rule. ${ }^{26,27}$ The low viscosity makes difficult to fabricate membranes, and the gas leakage in the membrane causes the lower 
performance as an electrolyte. ${ }^{28-31}$ Another issue associated with using ionic liquid is the insufficient transport number of proton. High mobility of both cations and anions results in a low transport number of protons. It leads to low open circuit voltage (OCV) in fuel cells. ${ }^{29,32}$

In this study, we propose a new approach for the design of proton conductor based on a CP glass synthesized from protic ionic liquid and metal ions. Appropriately selected metal ions interact with the anions to form $\mathrm{CP}$ with desirable characteristics of moldability, proton conductivity, as well as transport number. Here, a CP glass consisting of a protic ionic liquid (dema) $\left(\mathrm{H}_{2} \mathrm{PO}_{4}^{-}\right)\left(\right.$dema $=$diethylmethylammonium cation) and $\mathrm{Zn}^{2+}$ was synthesized. The proton conductivity, transport number, mechanical properties, and the resultant performance in a $\mathrm{H}_{2} / \mathrm{O}_{2}$ fuel cell under anhydrous conditions are reported along with the structural analysis of the coordination network.

\section{RESULTS AND DISCUSSION}

Synthesis and characterization

As a protic ionic liquid, (dema) $\left(\mathrm{H}_{2} \mathrm{PO}_{4}\right)$ (proton conductivity of $6.5 \mathrm{mS} \mathrm{cm}^{-1}$ at $120{ }^{\circ} \mathrm{C}$ ) is a candidate for further evaluation. ${ }^{25}$ The $\mathrm{H}_{2} \mathrm{PO}_{4}{ }^{-}$monoanion works both as a proton carrier and a bridging ligand (Fig. 1A left). In addition, $\mathrm{Zn}^{2+}$ is used as a metal ion, because its closed shell $\mathrm{d}^{10}$ electronic configuration makes it redox inactive. ${ }^{12,19,33}$ In zinc phosphate glasses, the formation of the coordination network is known to tune the physical properties, ${ }^{34,35}$ and the length of the coordination network depends on the ratio of $\mathrm{Zn}^{2+}$ to phosphates. ${ }^{36} \mathrm{The}^{2}$ amorphous compound containing $\mathrm{Zn}^{2+}$, dema, and $\mathrm{H}_{2} \mathrm{PO}_{4}^{-}$was synthesized by neutralization of zinc oxide $(\mathrm{ZnO})$, diethylmethylamine and phosphoric acid $\left(\mathrm{H}_{3} \mathrm{PO}_{4}\right)$ (Scheme $\mathrm{S} 1$ top). Grinding these materials, followed by a drying process, afforded $\mathbf{1}$ as a viscoelastic solid (Fig. 1A). As a reference for $\mathbf{1}$, we also prepared (dema) $\left(\mathrm{H}_{2} \mathrm{PO}_{4}\right)$ (2) according to the method available in the literature (Scheme S1 bottom)... ${ }^{25}$ 

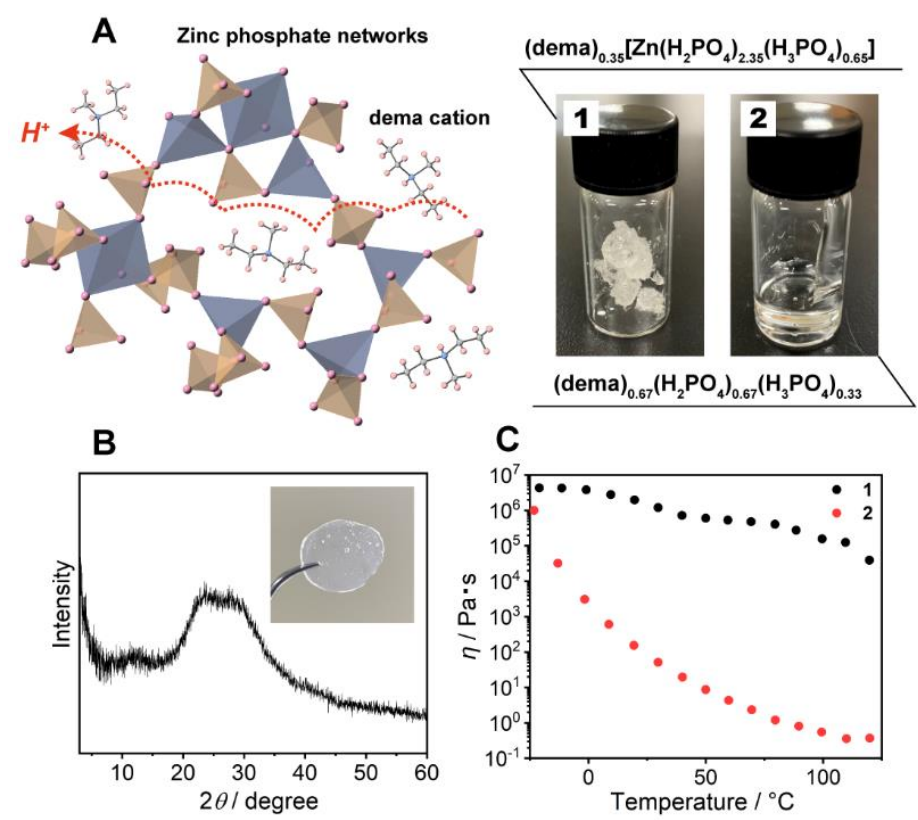

Fig. 1. (A) Schematic structurer of 1, the blue and orange polyhedra represent $\mathrm{Zn}^{2+}$ and $\mathrm{H}_{\mathrm{n}} \mathrm{PO}_{4}$, the captured organic ions are dema cations. The formula and digital photographs of 1 and 2 at $25^{\circ} \mathrm{C}$. (B) Powder X-ray diffraction (PXRD) pattern of $\mathbf{1}$. Inset shows a digital photograph of a monolith of $\mathbf{1}$ after annealing at $120^{\circ} \mathrm{C}$. (C) Temperature dependence of viscosity of $\mathbf{1}$ (black) and $\mathbf{2}$ (red).

The chemical compositions of $\mathbf{1}$ and $\mathbf{2}$ were characterized by solid-state magic angle spinning nuclear magnetic resonance (SSNMR) (Fig. S1) and elemental analysis. The proton peaks were assigned to either dema or $\mathrm{H}_{2} \mathrm{PO}_{4}{ }^{-} / \mathrm{H}_{3} \mathrm{PO}_{4}$, and both 1 and 2 contained no detectable water molecules. The observed integration value of the ${ }^{1} \mathrm{H}$ signals of dema (dema: $\left.\mathrm{H}_{2} \mathrm{PO}_{4}^{-}=1: 7.6\right)$ was different from the theoretical chemical composition of starting materials (dema: $\mathrm{H}_{2} \mathrm{PO}_{4}{ }^{-}=1: 3$ ). Previous reports identified that highly stable protic ionic liquids have a $\mathrm{p} K \mathrm{a}$ difference between the cation and the anion larger than $10 .{ }^{26,37}$ The difference of $\mathrm{pKa}$ value between $\mathrm{H}_{3} \mathrm{PO}_{4}(2.1)$ and diethylmethylammonium cation (10.5) is $\Delta \mathrm{pKa}$ of 8.4, and the neutral amine was partially evaporated during the drying process (Fig. 1A). Both SSNMR and elemental analysis indicated identical composition of 1, i.e., (dema) $)_{0.35}\left[\mathrm{Zn}\left(\mathrm{H}_{2} \mathrm{PO}_{4}\right)_{2.35}\left(\mathrm{H}_{3} \mathrm{PO}_{4}\right)_{0.65}\right]$. The partial evaporation of the amine was also observed for $2 .{ }^{25}$ The ${ }^{1} \mathrm{H}$ SSNMR gave the composition of 2 as $(\mathrm{dema})_{0.67}\left(\mathrm{H}_{2} \mathrm{PO}_{4}\right)_{0.67}\left(\mathrm{H}_{3} \mathrm{PO}_{4}\right)_{0.33}$. Furthermore, the ${ }^{31} \mathrm{P}$ SSNMR spectrum of 1 resulted in peaks at $0.2 \mathrm{ppm}\left(20^{\circ} \mathrm{C}\right.$, Fig. S2), which suggests that the phosphoric acid species remains in the form of orthophosphoric acid or its conjugate bases after drying. ${ }^{38-40}$ 
The powder X-ray $(\mathrm{CuK} a)$ diffraction (PXRD) pattern of $\mathbf{1}$ at room temperature exhibited no Bragg peaks, and $\mathbf{1}$ was amorphous (Fig. 1B). Thermal properties of $\mathbf{1}$ were subsequently determined by thermogravimetric analysis (TGA) and differential scanning calorimetry (DSC, Fig. S3). It can be seen that there is no weight loss up to $200{ }^{\circ} \mathrm{C}$. In addition, the DSC curves of 1 showed glass transition at $-22{ }^{\circ} \mathrm{C}$ and no first order phase transition corresponded to crystallization under the measurement conditions.

The mechanical properties of $\mathbf{1}$ were evaluated by viscosity (Fig. 2C) and dynamic mechanical analyses (DMA) (Fig. S4). The viscosity of $\mathbf{1}$ showed higher value than that of $\mathbf{2}$ in the measured temperature range ( -20 to $\left.120^{\circ} \mathrm{C}\right)$. The viscosity values of $\mathbf{1}$ are lower than the viscosity at the Littleton softening point $\left(10^{6.6}\right)$ and higher than that at the working point $\left(10^{4}\right) .{ }^{41}$ Soda-lime glass exhibits identical viscosity range at $700-800{ }^{\circ} \mathrm{C}$. The viscosity of 1 at room temperature to $120{ }^{\circ} \mathrm{C}$ is suitable for moldability to develop a large transparent monolith by an annealing process (Fig. 1B; inset). Furthermore, dynamic mechanical analysis of 1 also demonstrated higher shear modulus than that of $\mathbf{2}$. The $G$ " (the loss modulus) of $\mathbf{1}$ is lower than $G^{\prime}$ (the storage modulus) at each temperature $\left(-20\right.$ to $\left.120^{\circ} \mathrm{C}\right)$. This suggests that $\mathbf{1}$ has no fluidity above the glass transition temperature.

\section{Structural analysis and modeling}

We subsequently characterized the amorphous structure of $\mathbf{1}$. The X-ray absorption fine structure (XAFS) analysis was used for coordination geometry and average coordination number of $\mathrm{Zn}^{2+}$ in $1 .{ }^{42-44}$ The XAFS spectra of the $K$-edge region of $\mathrm{Zn}^{2+}$ for 1 and the reference samples were measured and analyzed (Fig. S5). As references, three $\mathrm{Zn}^{2+}$ salts possessing different coordination geometries, i.e., $\mathrm{ZnO}$ (tetrahedral), $\mathrm{Zn}\left(\mathrm{SO}_{4}\right) \cdot 7 \mathrm{H}_{2} \mathrm{O}$ (octahedral), and $\mathrm{Zn}_{3}\left(\mathrm{PO}_{4}\right)_{2} \cdot 4 \mathrm{H}_{2} \mathrm{O}$ (tetrahedral:octahedral $\left.=2: 1\right)^{45}$ were used. The edges of the spectra of reference samples showed a relationship between the energy and the coordination number. The X-ray absorption near edge structure (XANES) region of 1 (Fig. 2A) demonstrated similar energy and shape to that of the model crystal $\mathrm{Zn}_{3}\left(\mathrm{PO}_{4}\right)_{2} \cdot 4 \mathrm{H}_{2} \mathrm{O}$, which indicates that the averaged coordination number of $\mathbf{1}$ is in the range of 4-6, and close to 4.67 (tetrahedral:octahedral $=2: 1$ ). The resulting $k^{3}$ weighted radial distribution function of 1 was fitted using the FEFF calculation (Fig. 2B). The obtained converged parameter gave a reasonable coordination number (4.6 \pm 0.4$)$, which is close to the proposed model $\mathrm{Zn}_{3}\left(\mathrm{PO}_{4}\right)_{2} \cdot 4 \mathrm{H}_{2} \mathrm{O}$. The fitted coordination number of 4.6 can only be explained by some of $\mathrm{H}_{2} \mathrm{PO}_{4}{ }^{-} / \mathrm{H}_{3} \mathrm{PO}_{4}$ coordinating more than two $\mathrm{Zn}^{2+}$ ions. These results suggest that $\mathrm{H}_{2} \mathrm{PO}_{4}{ }^{-}$acts as a bridging ligand, and that a $\mathrm{Zn}^{2+}-\mathrm{H}_{2} \mathrm{PO}_{4}^{-} / \mathrm{H}_{3} \mathrm{PO}_{4}$ coordination network structure is formed in $\mathbf{1}$. 

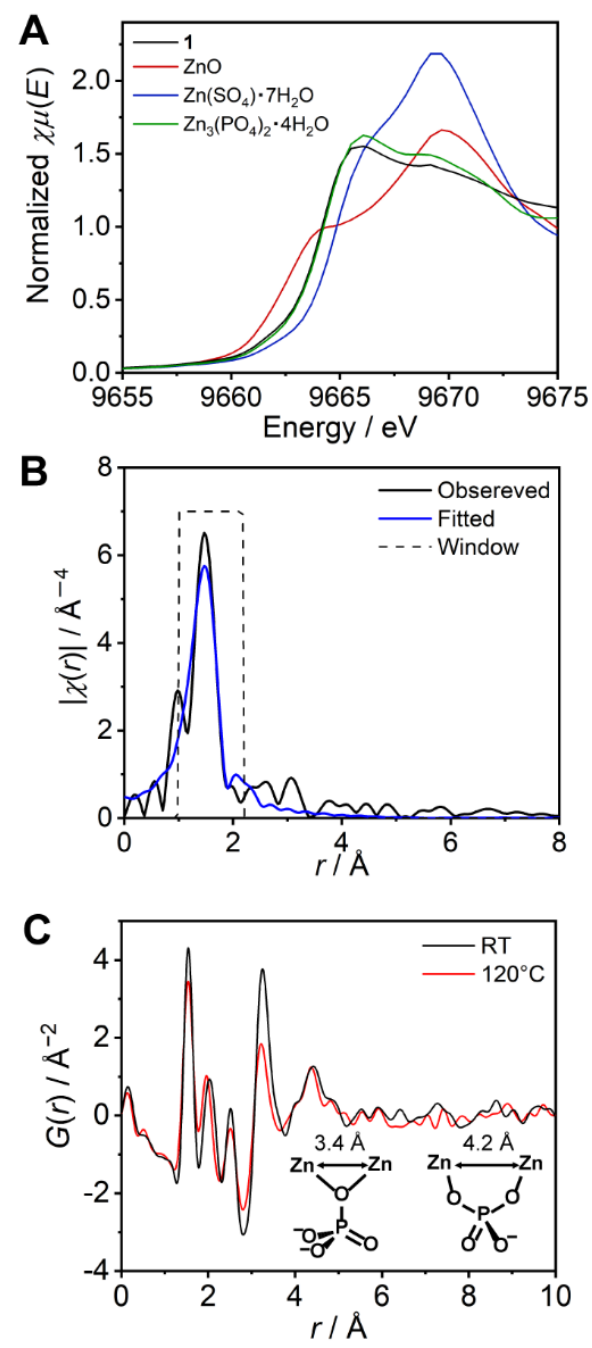

Fig. 2. (A) XANES region of the XAFS spectra of $\mathrm{Zn} \mathrm{K}$-edge of 1 (black) and references: $\mathrm{ZnO}$ (red), $\mathrm{Zn}\left(\mathrm{SO}_{4}\right) \cdot 7 \mathrm{H}_{2} \mathrm{O}$ (blue), and $\mathrm{Zn}_{3}\left(\mathrm{PO}_{4}\right)_{2} \cdot 4 \mathrm{H}_{2} \mathrm{O}$ (green). (B) Radial distribution functions (RDF) of $\mathbf{1}$ (black line) and fitting curve (blue line). (C) Reduced pair distribution function (PDF) profile of 1 and $\mathrm{Zn}^{2+}-\mathrm{Zn}^{2+}$ distances.

The reduced pair distribution function (PDF), $G(r)$, was conducted using wide $Q$ range diffraction measured at the synchrotron (Incident energy $=61.377 \mathrm{keV}$ ). The $G(r)$ of $\mathbf{1}$ are presented in Fig. 2C. Five distinct peaks (at $1.54,2.03,2.513 .25$, and $4.42 \AA$ ) are observed below $5 \AA$. A related crystal structure of zinc phosphate $\left(\mathrm{Zn}_{3}\left(\mathrm{PO}_{4}\right)_{2} \cdot 4 \mathrm{H}_{2} \mathrm{O}\right)^{45}$ was used to consider the possible $\mathrm{Zn}^{2+}-\mathrm{Zn}^{2+}$ distances in the $\mathrm{Zn}^{2+}-\mathrm{H}_{2} \mathrm{PO}_{4}^{-} / \mathrm{H}_{3} \mathrm{PO}_{4}$ network structures. In the model crystal structure, two types of $\mathrm{Zn}^{2+}-\mathrm{Zn}^{2+}$ distances shorter than $5 \AA$ were found. The shortest $\mathrm{Zn}^{2+}-\mathrm{Zn}^{2+}$ distance (3.38 $\AA$ ) was formed via one $\mu$-oxygen atom of the $\mathrm{PO}_{4}{ }^{3-}$ anion. Another $\mathrm{Zn}^{2+}-\mathrm{Zn}^{2+}$ distance (4.22 $\AA$ ) bridged by two oxygen atoms of a $\mathrm{PO}_{4}{ }^{3-}$ was also found (Fig. $2 \mathrm{C}$ inset). The peaks obtained 
experimentally are in good agreement with the two aforementioned $\mathrm{Zn}^{2+}-\mathrm{Zn}^{2+}$ distances. In addition to the comparison with the model crystal, the atomic scattering factor of $\mathrm{Zn}^{2+}$ is much higher than that of the other atoms. Therefore, the two peaks (3.25 and $4.42 \AA$ ) can be assigned to $\mathrm{Zn}^{2+}-\mathrm{Zn}^{2+}$. The PDF measured at $120^{\circ} \mathrm{C}$ also showed similar five peaks. The $\mathrm{Zn}-\mathrm{Zn}$ correlations are retained at high temperature even the intensity of the peak at $3.3 \AA$ is slightly lower than that obtained at room temperature. The XAFS and PDF analyses of $\mathbf{1}$ suggest the formation of coordination networks.

The coordination network structure was demonstrated by reverse Monte Carlo (RMC) structural modeling using X-ray experimental structural factor $S(Q)$ and EXAFS $k^{3} \chi(k)$ data with several coordination number constraints. In the present study, the atoms (Zn:60, P:180, O:720, N:21, C:105, H:693) were placed in a cubic box. The size of the cubic box was determined by the experimental density $\left(1.87 \mathrm{~g} \mathrm{~cm}^{-3}\right)$ at room temperature. The calculated $S(Q)$ (Fig. 3A) and $k^{3} \chi(k)$ (Fig. 3B) of the RMC structural modeling indicated good agreement with the experimental values. The resulting RMC modeling structure of a cubic unit cell was presented in Fig. 3C. The averaged coordination number of $\mathrm{Zn}^{2+}$ is 4.4 , which is close to that obtained by the XAFS measurements (4.6). The obtained CP structure contains all $60 \mathrm{Zn}^{2+}$ atoms and $147 \mathrm{H}_{2} \mathrm{PO}_{4}^{-} / \mathrm{H}_{3} \mathrm{PO}_{4}$ molecules (Fig. 3C bottom left). In the structure, dema and free $\mathrm{H}_{2} \mathrm{PO}_{4}^{-} / \mathrm{H}_{3} \mathrm{PO}_{4}$ are surrounded by the three-dimensional coordination networks (Fig. $3 \mathrm{C}$ bottom right). The RMC modeling structure suggests that bulky dema and free $\mathrm{H}_{2} \mathrm{PO}_{4}{ }^{-} / \mathrm{H}_{3} \mathrm{PO}_{4}$ are accommodated within the coordination networks. The structure plays a role of exclusive proton conductivity with a low energy barrier. 

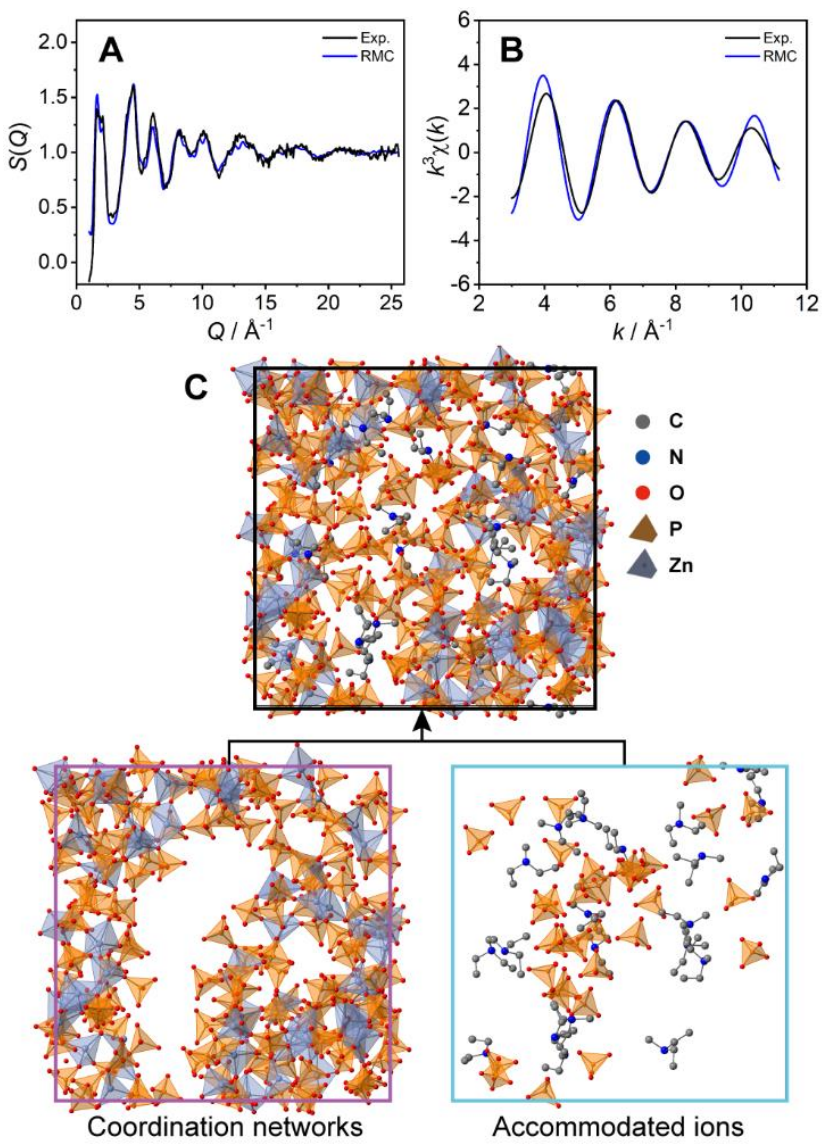

Fig. 3. Comparison of the experimental data (black line) and the results of the RMC structural modeling (blue line) for 1. (A) X-ray total structure factor $S(Q)$ and (B) EXAFS $k^{3} \chi(\mathrm{k})$. The EXAFS $\mathrm{k}^{3} \chi(\mathrm{k})$ were obtained by back Fourier transformation of $|\mathrm{FT}(\mathrm{R})|$ of the first correlation peak. (C) The unit cell of amorphous structure of 1 modeled by RMC. The coordination network and captured free dema and $\mathrm{H}_{2} \mathrm{PO}_{4}{ }^{-} / \mathrm{H}_{3} \mathrm{PO}_{4}$ are separately presented.

\section{Proton conductivity}

Ion conductivity of $\mathbf{1}$ was determined by variable temperature $\mathrm{AC}$ impedance spectroscopy under dry inert atmosphere (Fig. 4A and S6). The Nyquist plots at $120^{\circ} \mathrm{C}$ are shown with the fitted curves from an equivalent circuit model (Fig. S7). The equivalent circuit contains R1, R2, and Q1, where, R1 is the bulk resistance of $\mathbf{1}$ or $\mathbf{2}$, and parallel connection of R2 and Q1 represents combined resistance and constant phase elements from the electric double layer, respectively (Fig. S8, S9). ${ }^{46}$ The conductivity of $\mathbf{1}$ is higher than that of $\mathbf{2}$ at each temperature. The conductivity reached $\sigma=13.3 \mathrm{mS} \mathrm{cm}-1$ at $120^{\circ} \mathrm{C}$, which is approximately twice as high as that of $2\left(\sigma=6.5 \mathrm{mS} \mathrm{cm}^{-1}\right)$. The lower the viscosity, the higher the observed conductivity of the ionic liquid is due to the contribution of the vehicle mechanism. ${ }^{26}$ The conductivity of $\mathbf{1}$ is higher than that of $\mathbf{2}$, whereas the viscosity 
of $1\left(\log \eta^{-1}=-5.6 \mathrm{P}^{-1}\right.$ at $\left.120^{\circ} \mathrm{C}\right)$ is significantly higher than that of $2\left(\log \eta^{-1}=-0.57 \mathrm{P}^{-1}\right.$ at $\left.120{ }^{\circ} \mathrm{C}\right)$. This suggests that in comparison to $\mathbf{2}$, the proton-conducting mechanism of $\mathbf{1}$ is dominated more by the Grotthuss mechanism. The temperature dependence of both $\mathbf{1}$ and $\mathbf{2}$ showed non-Arrhenius type plots which are frequently seen in ionic liquids and their polymer composites. ${ }^{37,47}$ The profiles were analyzed by curve fitting using the Vogel-Fulcher-Tammann (VFT) equation (eq. 1) to obtain the parameters for proton conductivity. ${ }^{48-50}$

The resulting fitting parameters are in good agreement with the experimental results (Fig. 4A, solid lines) and are summarized in Table S1. The smaller A value of $\mathbf{1}$ than that of $\mathbf{2}$ suggests that the concentration of ions does not contribute to higher conductivity. The higher conductivity of $\mathbf{1}$ is attributed to lower pseudo activation energy B by the coordination network formation.

A
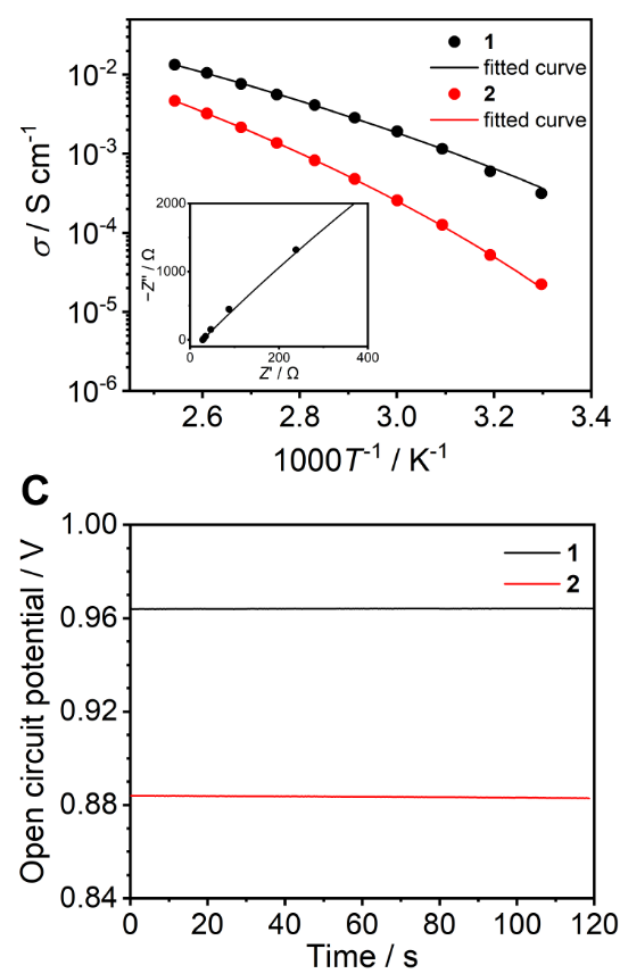

B
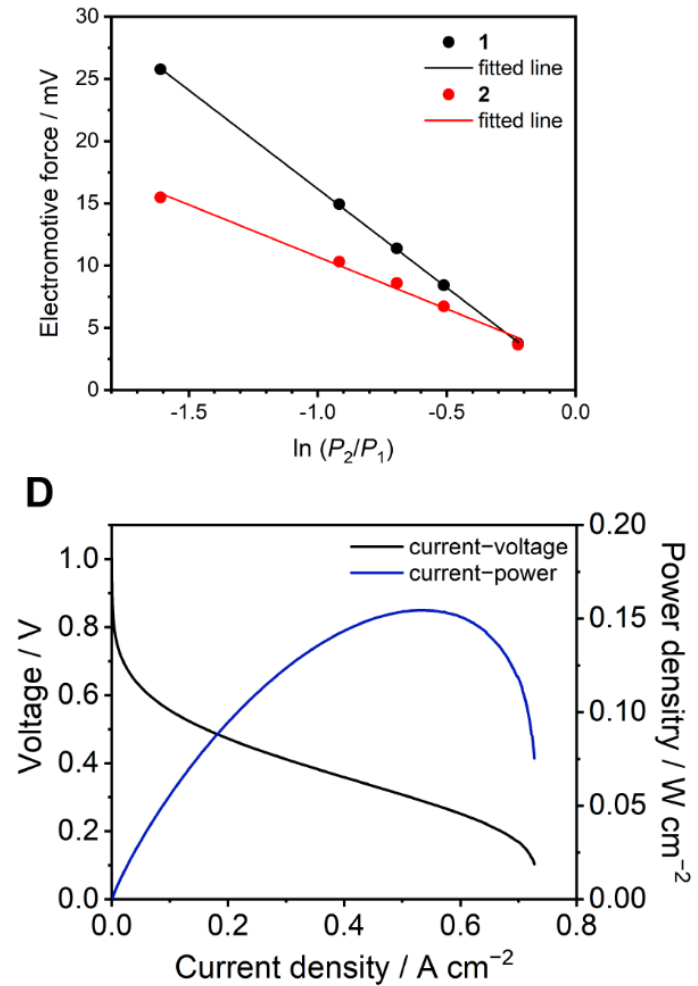

Fig. 4. (A) Ion conductivity of $\mathbf{1}$ (black) and $\mathbf{2}$ (red) as a function of temperature under anhydrous conditions. The solid lines are the fitting curves determined using the VFT equation (eq 1). Inset exhibits the Nyquist plots of 1 at $120^{\circ} \mathrm{C}$. (B) Electromotive force of $\mathbf{1}$ and $\mathbf{2}$ measured under different relative hydrogen gas pressure. (C) OCV of $\mathbf{1}$ in a $\mathrm{H}_{2} / \mathrm{O}_{2}$ fuel cell at $120^{\circ} \mathrm{C}$ without humidification. (D) $\mathrm{I}-\mathrm{V}$ and $\mathrm{I}-\mathrm{W}$ curves of a $\mathrm{H}_{2} / \mathrm{O}_{2}$ fuel cell with $\mathbf{1}$ as an electrolyte at $120^{\circ} \mathrm{C}$ without humidification. Black and blue lines represent the current-voltage and current-power plots, respectively. 
The transport number is defined as the ratio of the electric current derived from a ion of interest or target ion to the total electric current. ${ }^{51}$ In the case of protic ionic liquids, transport number is usually in the range of $0.5-0.6$ which means that the counter anions contribute to the ion conduction. ${ }^{25,52-54}$ The transport numbers of $\mathbf{1}$ and $\mathbf{2}$ were determined by electromotive force (EMF) measurements between different hydrogen partial pressure values $\left(\ln \left(P_{1} / P_{2}\right)=0.22,0.51,0.69,0.92,1.61\right)$ (Fig. 4B) using equation 2 (eq. 2). ${ }^{55}$ The resulting transport number of 1 is $\mathbf{0 . 9 4}$, which indicates that the ion conductivity of $\mathbf{1}$ is predominantly attributed to proton. On the other hand, the obtained transport number for $\mathbf{2}$ is 0.49 . The high transport number of $\mathbf{1}$ suggests that the movement of anions in $\mathbf{1}$ is significantly suppressed. To confirm the impact of the high transport number of $\mathbf{1}$, we measured the OCV in a $\mathrm{H}_{2}{ }^{\prime} \mathrm{O}_{2}$ fuel cell at $120^{\circ} \mathrm{C}$ (Fig. $4 \mathrm{C}$ ). The $\mathrm{OCV}$ of $\mathbf{1}$ is $0.96 \mathrm{~V}$ and it is intact over 10 minutes. It is also higher than that of $2(0.88 \mathrm{~V})$. While the observed OCV of $\mathbf{1}$ is lower than the theoretical value of $1.16 \mathrm{~V}$ at $120{ }^{\circ} \mathrm{C},{ }^{56}$ it is comparative to the highest $\mathrm{OCV}$ values of $\mathrm{CP} / \mathrm{MOF}$ and protic ionic liquids at $120{ }^{\circ} \mathrm{C}$ reported so far. ${ }^{17,31,57}$

The I-V curve of a $\mathrm{H}_{2} / \mathrm{O}_{2}$ fuel cell with 1 was determined at $120^{\circ} \mathrm{C}$ under anhydrous conditions (Fig. 4D). The electrolyte membrane was prepared by impregnation of $\mathbf{1}$ into a polytetrafluoroethylene (PTFE) membrane. The I-V curve was measured using $100 \% \mathrm{H}_{2}$ and $\mathrm{O}_{2}$ gases. We also attempted to evaluate the $\mathrm{I}-\mathrm{V}$ curve for $\mathbf{2}$, however, this was unsuccessful under the same conditions. This is because of high fluidity, and hard to suppress gas permeation using 2 as the electrolyte. The observed maximum power density was $150 \mathrm{mWcm}^{-2}$. Among the fuel cell performance at $120^{\circ} \mathrm{C}$, this value is higher than that of the reported $\mathrm{CP} / \mathrm{MOFs}\left(2.8 \mathrm{~mW} \mathrm{~cm}^{-2}\right.$ under relative humidity $(\mathrm{RH})=26 \%),{ }^{17}\left(12 \mathrm{~mW} \cdot \mathrm{cm}^{-2}\right.$ at $180{ }^{\circ} \mathrm{C}$ under anhydrous conditions $),{ }^{58}$ xerogels $\left(0.94 \mathrm{~mW} \mathrm{~cm}^{-2}\right.$ under anhydrous condition), ${ }^{59}$ and membrane composite of protic ionic liquids $\left(63 \mathrm{~mW} \mathrm{~cm}{ }^{-2}\right.$ under dry condition $)^{29,54}$ and as high as the composite of functionalized graphene oxide and Nafion $\left(150 \mathrm{~mW} \mathrm{~cm}^{-2}\right)$ measured under humidified conditions $(\mathrm{RH}=25 \%){ }^{60}$

To describe the dynamics of the coordination network and proton in 1, we carried out ${ }^{1} \mathrm{H}$ SSNMR from 0 to $100{ }^{\circ} \mathrm{C}$ for 1 and 2 (Fig. 5A). The chemical shifts of proton on aliphatic carbons of dema (4-1 ppm) were independent of the temperature and were identical for $\mathbf{1}$ and $\mathbf{2}$. On the other hand, the proton signals of $\mathrm{H}_{2} \mathrm{PO}_{4}^{-} / \mathrm{H}_{3} \mathrm{PO}_{4}$ were observed at 10-9.5 ppm (1) and 11-10.4 ppm (2), respectively. Hydrogen bond formation has been previously reported in protic ionic liquids containing proton-donating and -accepting anions such as $\mathrm{HSO}_{4}{ }^{-}$ and $\mathrm{H}_{2} \mathrm{PO}_{4}{ }^{-}{ }^{27,31,61}$ When the hydrogen bonds are formed in liquid states or solutions, downfield shifts are often observed. ${ }^{24}$ The dimer formation via two hydrogen bonds in $\mathrm{H}_{2} \mathrm{PO}_{4}{ }^{-}$is formed and these protons trapped by dimer structure is not favorable for proton conduction. ${ }^{62,63}$ The presence of $\mathrm{Zn}^{2+}$ decreases the hydrogen bonds between $\mathrm{H}_{2} \mathrm{PO}_{4}{ }^{-} / \mathrm{H}_{3} \mathrm{PO}_{4}$ by forming a coordination network. Considering the temperature dependence of $\mathbf{1}$, only acidic 
proton exhibited a relatively high dependence of the chemical shifts and peak broadening on the temperature, whereas both cations and anions of $\mathbf{2}$ showed temperature-dependent broadening. This difference suggests that the conductivity of $\mathbf{1}$ is mainly affected by proton of $\mathrm{H}_{2} \mathrm{PO}_{4}{ }^{-} / \mathrm{H}_{3} \mathrm{PO}_{4}$, which is in accordance with other measurements. It was reported that the ion conductivities of protic ionic liquids are related not only to proton but also to cations and anions. ${ }^{31}$ The observed spin-spin relaxation time $\left(T_{2}\right)$ of $\mathbf{2}$ is much longer than that of $\mathbf{1}$ at the temperature region of $0-100{ }^{\circ} \mathrm{C}$ (Fig. 5B). The shorter $\mathrm{T}_{2}$ for $\mathbf{1}$ means that it exhibits more solid-like behavior, and $\mathbf{2}$ is a more isotropic fluid state. These SSNMR analyses also support the observation that the coordination networks in 1 enhance the proton conductivity and increase the transport number.
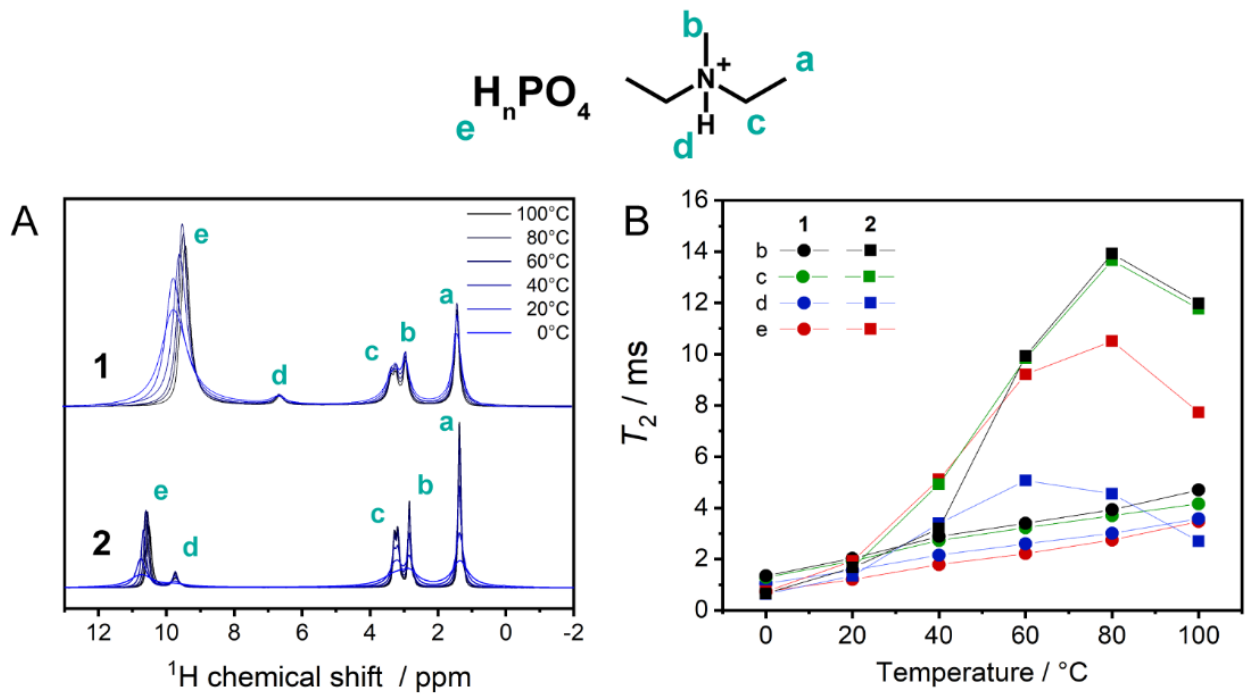

Fig. 5. (A) ${ }^{1} \mathrm{H}$ SSNMR spectra of 1 and 2 from 0 to $100{ }^{\circ} \mathrm{C}$ including the assignments of protons. (B) $T_{2}$ of ${ }^{1} \mathrm{H}$ SSNMR signals of $\mathbf{1}$ (circle) and $\mathbf{2}$ (square) at each temperature.

In summary, we propose an approach for creating a CP glass from a protic ionic liquid for solid-state anhydrous proton conductor. The reaction of $\mathrm{Zn}^{2+}$ and protic ionic liquid (dema) $\left(\mathrm{H}_{2} \mathrm{PO}_{4}{ }^{-}\right)$was shown to result in the formation of a $\mathrm{Zn}^{2+}-\mathrm{H}_{2} \mathrm{PO}_{4}^{-} / \mathrm{H}_{3} \mathrm{PO}_{4}$ network structure accommodating dema cations. The synthesized compound 1 is a glassy solid exhibiting sufficient mechanical strength to form a membrane. The glassy solid $\mathbf{1}$ shows higher proton conductivity $\left(13.3 \mathrm{mS} \mathrm{cm}{ }^{-1}\right)$ than that of liquid state (dema) $\left(\mathrm{H}_{2} \mathrm{PO}_{4}\right)(2)$ at $120^{\circ} \mathrm{C}$. The structure was characterized by XAFS and PDF, which indicate the formation of a coordination network structure. The threedimensional structure was proposed by RMC and was in good agreement with the experimental data.

Formation of the extended networks prohibits the moving of both cations (dema) and anions $\left(\mathrm{H}_{2} \mathrm{PO}_{4}^{-}\right)$. Consequently, we observed exclusive proton conduction in the structure. This is confirmed by the high transport 
number $(0.94)$ and OCV $(0.96 \mathrm{~V})$, both of which are the essential factors for electrolyte in fuel cell. These protonconducting and viscoelastic properties of 1 demonstrated improved performance in a $\mathrm{H}_{2} / \mathrm{O}_{2}$ fuel cell at $120{ }^{\circ} \mathrm{C}$ $\left(0.15 \mathrm{~W} \mathrm{~cm}^{-2}\right)$ without humidification. The characteristic proton conducting properties and structural analyses indicate that the coordination network formation with protic ionic liquids is a promising route for the modification of mechanical properties and proton conductivity of electrolytes.

\section{METHODS}

Synthesis of 1: $\mathrm{ZnO}(3.25 \mathrm{~g}, 0.04 \mathrm{~mol})$ and 3 equimolar of phosphoric acid (85\%) $(8.18 \mathrm{~mL}, 0.12 \mathrm{~mol})$ were mixed and grinded in a mortar until form transparent colorless liquid, then, excess $\mathrm{H}_{3} \mathrm{PO}_{4}$ was neutralized by addition of 1 equimolar diethylmethylamine $(4.84 \mathrm{~mL}, 0.04 \mathrm{~mol})$ and grinding for $30 \mathrm{~min}$. Then resulting transparent colorless liquid was transferred to a round bottom flask and dried under reduced pressure at room temperature for $8 \mathrm{~h}$ and then at $120^{\circ} \mathrm{C}$ for $2 \mathrm{~h}$. After cooling to room temperature, transparent high viscoelastic colorless material was obtained (13.9 g). The chemical composition of 1 was determined by solid-state NMR and elemental analysis. (dema) $)_{0.35}\left[\mathrm{Zn}\left(\mathrm{H}_{2} \mathrm{PO}_{4}\right)_{2.35}\left(\mathrm{H}_{3} \mathrm{PO}_{4}\right)_{0.65}\right]$. Elemental analysis calcd for $\mathrm{C}_{1.75} \mathrm{H}_{11.55} \mathrm{~N}_{0.35} \mathrm{O}_{12} \mathrm{P}_{3} \mathrm{Zn}$ : $\mathrm{C}$, 5.42; H, 3.00; N, 1.26, found C, 5.64; H, 3.36; N, 1.30. Density $=1.87 \mathrm{~g} \mathrm{~cm}^{-3}$.

Characterization. Thermogravimetric analysis (TGA) were recorded using Rigaku TG8120 instrument under flowing $\mathrm{N}_{2}$ with $10 \mathrm{~K}$ min-1 scan rate. Differential Scanning Calorimetry (DSC) experiments were measured using Hitachi DSC 7020 instrument in an inert argon atmosphere. Variable-temperature viscoelastic measurement was performed by using a rotational parallel-plate rheometer (Rheosol-G5000, UBM Co., Ltd.) under dry $\mathrm{N}_{2}$ flow with applying oscillatory strain of $1 \mathrm{~Hz}$. The sample-holding gap was set to $1.0 \mathrm{~mm}$. Laboratory scale powder Xray radiation diffraction patterns were collected on a Rigaku SmartLab multipurpose diffractometer $(\mathrm{CuK} \alpha ; \lambda=$ $1.540598 \AA)$.

Extended X-ray Absorption Fine-Structure Spectroscopy were collected on beamline BL14B2 at SPring-8. Xray absorption spectra in the energy region of the Zn K-edge were measured in transmission mode. Fourier transformation was $k^{3}$-weighted in the $k$ range from 3.0 to $12.5 \AA^{-1}$. The data processing and coordination number fitting were performed with Athena and Artemis software, respectively. All samples were measured under Ar atmosphere. The resulting k3-weighted radial distribution function of $\mathbf{1}$ was fitted by a FEFF calculation ${ }^{64}$ using first $\mathrm{Zn}-\mathrm{O}$ single scattering path of $\mathrm{Zn}\left(\mathrm{SO}_{4}\right) \cdot 7 \mathrm{H}_{2} \mathrm{O}$.

$\mathrm{X}$-ray total scattering data were collected with four CdTe and two Ge detectors covering the $Q$ range up to 25 $\AA^{-1}$ at SPring-8 on beamline BL04B2 $(61.377 \mathrm{keV} ; \lambda=0.2020 \AA)$. The collected scattering data was applied absorption, background, and Compton scattering corrections, and then normalized to give the Faber-Ziman total 
structure factor $S(Q) .{ }^{65,66}$ Then, the pair distribution function was calculated by Fourier transforming the $S(Q)$ with a Lorch modification function. ${ }^{67}$

Reverse Monte Carlo structural modeling of amorphous state of $\mathbf{1}$ (a cubic cell; $a=b=c=27.44 \AA$ ) was performed using the RMC++ program. ${ }^{68}$ The initial configuration was generated by hard-sphere Monte Carlo simulations with constraints applied to avoid unrealistic structures. The closest distance, bond angles and bond length constraints ware performed to form reasonable diethylmethylammonium cations and $\mathrm{H}_{2} \mathrm{PO}_{4}{ }^{-} / \mathrm{H}_{3} \mathrm{PO}_{4}$ structures. The closest atom-atom distance was chosen based on the information from related crystal structures of $\mathrm{TBA}\left(\mathrm{H}_{2} \mathrm{PO}_{4}\right)$ and $\mathrm{Zn}_{3}\left(\mathrm{PO}_{4}\right)_{2} \cdot 4 \mathrm{H}_{2} \mathrm{O}$. After the hard-sphere Monte Carlo simulations, RMC simulations containing $\mathrm{X}$-ray $S(Q)$ and $k^{3} c(k)$ EXAFS data were performed with the constraint of averaged coordination number of $\mathrm{Zn}-\mathrm{O}$ $=4.6$. The EXAFS back scattering tables were prepared by the $\mathrm{FEFF}^{69}$ calculations. The reported atomic scattering factors and anomalous scattering factors of each atoms were used for these calculations.

Solid-state NMR experiments were performed on JNM-ECZ600R spectrometer (JEOL RESONANCE Inc., Japan) at $14.01 \mathrm{~T}$ with a ${ }^{1} \mathrm{H}$ resonance frequency of $599.7 \mathrm{MHz}$, equipped with a $2.0 \mathrm{~mm}$ double resonance MAS probe (JEOL RESONANCE Inc, Japan). 1D ${ }^{1} \mathrm{H}$ and ${ }^{31} \mathrm{P}$ spectra, and ${ }^{1} \mathrm{H} T_{2}$ relaxation time were measured by single pulse and spin-echo pulse sequence, respectively, at $20 \mathrm{kHz}$ spinning rate in the temperature range of 0$100{ }^{\circ} \mathrm{C}$. RF field strength of ${ }^{1} \mathrm{H}$ and ${ }^{31} \mathrm{P}$ nuclei was $121.95 \mathrm{kHz}$ at the $\pi / 2$ pulse width of $1.98 \mu$ s and $131.58 \mathrm{kHz}$ at the $\pi / 2$ pulse width of $1.9 \mu \mathrm{s}$, respectively. The spectra were processed with the Delta software (JEOL RESONANCE Inc).

Electrochemical measurements

Impedance spectra from $30{ }^{\circ} \mathrm{C}$ to $120{ }^{\circ} \mathrm{C}$ under Ar atmosphere were collected using a BioLogic VSP-300 with an EC Frontier sample cell (SB1A, $\phi=13 \mathrm{~mm}, d=5 \mathrm{~mm}$ ). The frequency ranges from $0.1 \mathrm{~Hz}$ to $1.0 \mathrm{MHz}$ with a sinus voltage $(10 \mathrm{mV})$ was collected at each temperature. The measurements were performed at thermal equilibrium after holding $30 \mathrm{~min}$ at each temperature. Collected impedance data were treated and analyzed by a ZView software. The VFT fitting (Levenberg-Marquardt Method) was performed using following equation 1 in an Origin 2018 software.

$$
\sigma(T)=A \exp \left(\frac{-B}{T-T_{0}}\right)
$$

$A$ is proportional to the concentration of the carrier ions, $B$ is the pseudo activation energy for the ion conduction, while $T_{0}$ is the ideal glass transition temperature.

Proton Transport number $\left(t_{\mathrm{H}^{+}}\right)$was determined by the electromotive force (EMF) measurements using a BioLogic VSP-300. A membrane filter (Omnipore ${ }^{\mathrm{TM}}$ Merck, $10.0 \mathrm{~mm}, 2 \times 2 \mathrm{~cm}$ ) was impregnated with 1 or 2 at $120^{\circ} \mathrm{C}$ or at room temperature, respectively. The membrane was then sandwiched between Pt loaded carbon 
papers (1.5 mg cm${ }^{-2}, \phi=5 \mathrm{~mm}$, Chemix Co. Ltd.) and placed into a single cell with straight gas flow channels. On one side $\mathrm{H}_{2} / \mathrm{Ar}$ (3.99 vol\%,) was fed continuously while on the other side the $\mathrm{H}_{2} / \mathrm{Ar}$ gas was diluted with $\mathrm{N}_{2}$ ( 99.99995 vol\%) gas to achieve variable partial pressures. The $\mathrm{H}_{2}$ concentration was precisely controlled by mass flow controllers (SEC-E40, Horiba, ltd.) while maintaining total gas flow rate of $100 \mathrm{~mL} / \mathrm{min}$ on both the sides. The assembly was maintained at desired temperature using Oven and stabilized for $\sim 10$ min before measurement. The EMF generated between the sensing and counter electrodes were measured under different $\mathrm{H}_{2}$ partial pressures $\left(P_{2}\right)$ on equilibrating for $3 \mathrm{~min}$. The proton transport number $\left(t_{\mathrm{H}^{+}}\right)$is calculated using following equation

$$
E=t \frac{R T}{2 F} \ln \left(\frac{P_{1}}{P_{2}}\right)(\text { eq. } 2)
$$

$E, T, R, F, P_{1}, P_{2}$, and $t$ denote EMF, temperature, the gas constant, Faraday constant, partial pressure of $\mathrm{H}_{2}$ gas, and transport number, respectively. The polarization curves of a $\mathrm{H}_{2} / \mathrm{O}_{2}$ fuel cell were recorded using a Solartron SI 1287. Gas diffusion electrodes $\left(0.3 \mathrm{mg} / \mathrm{cm}^{2}, 46.5 \mathrm{wt} \% \mathrm{Pt} / \mathrm{C}\right)$ for both cathode and anode were fabricated by spray coating of $46.5 \mathrm{wt} \% \mathrm{Pt} / \mathrm{C}$ (TEC10E50E, Tanaka Kikinzoku, ltd.) onto the carbon paper gas diffusion layer (Sigracet $^{\circledR} 29$ BC, SGL Carbon, GmbH.). A membrane electrode assembly (MEA) was prepared by sandwiching the electrolyte membrane between two gas diffusion electrodes, and the contact area between electrode and electrolyte were $\phi=7 \mathrm{~mm}$. The resulting MEA was installed into a single cell with straight gas flow channels, and the dry $\mathrm{H}_{2}(>99.999 \mathrm{vol} \%)$ and $\mathrm{O}_{2}(>99.999 \mathrm{vol} \%)$ gases were supplied to the single cell at a flow rate of both $100 \mathrm{~mL} / \mathrm{min}$ under anhydrous conditions. The flow rate was controlled by mass flow controllers (SEC-E40, Horiba, ltd.). The polarization curves of the single cell were measured at $120^{\circ} \mathrm{C}$.

\section{ACKNOWLEDGEMENTS}

The work was supported by the Japan Society of the Promotion of Science (JSPS) for a Grant-in-Aid for Scientific Research (B) (JP18H02032) from the Ministry of Education, Culture, Sports, Science and Technology, Japan, and Strategic International Collaborative Research Program (SICORP) and Adaptable and Seamless Technology Transfer Program through Target-driven R\&D (A-STEP) from the Japan Science and Technology, Japan. The synchrotron radiation experiments were performed using the BL14B2, BL02B2 and BL04B2 beamlines at SPring8 with the approval of JASRI (Proposal No. 2018A1753, 2018B1311 and 2019A1292). We acknowledged to Dr. Naoki Ogiwara for XAFS measurements.

\section{AUTHOR CONTRIBUTIONS}

T.O. contributed to the synthesis and general characterization and analysis. K.T. performed the measurements of fuel cell tests. S.S.N. carried out the transport number determination. K.O. supported the PDF analysis and 
RMC structural modeling. Y.-L.H. and Y. N. collected and analyzed the SSNMR characterization. S. H. designed and conducted the entire study. All authors contributed to the writing and discussion.

\section{SUPPLEMENTARY INFORMATION}

VFT fitting parameters, ${ }^{1} \mathrm{H}$ and ${ }^{31} \mathrm{P}$ SSNMR spectra, XAFS spectra, TG, DSC, Nyquist plots and DMA properties.

\section{COMPETING INTERESTS}

The authors declare no competing financial interests.

\section{REFERENCES}

1. Li, Q.; He, R.; Jensen, J. O.; Bjerrum, N. J. Approaches and Recent Development of Polymer Electrolyte Membranes for Fuel Cells Operating above $100{ }^{\circ} \mathrm{C}$. Chem. Mater. 2003, 15, 4896-4915.

2. Zhang, H.; Shen, P. K. Recent Development of Polymer Electrolyte Membranes for Fuel Cells. Chem. Rev. 2012, 112, 2780-2832.

3. Chandan, A.; Hattenberger, M.; El-Kharouf, A.; Du, S. F.; Dhir, A.; Self, V.; Pollet, B. G.; Ingram, A.; Bujalski, W. High Temperature (HT) Polymer Electrolyte Membrane Fuel Cells (PEMFC) - a Review. J. Power Sources 2013, 231, 264-278.

4. Lemmon, J. P. Energy: Reimagine Fuel Cells. Nature 2015, 525, 447-449.

5. Wieser, C. Novel Polymer Electrolyte Membranes for Automotive Applications - Requirements and Benefits. Fuel Cells 2004, 4, 245-250.

6. $\quad$ Cano, Z. P.; Banham, D.; Ye, S.; Hintennach, A.; Lu, J.; Fowler, M.; Chen, Z. Batteries and Fuel Cells for Emerging Electric Vehicle Markets. Nature Energy 2018, 3, 279-289.

7. Steele, B. C.; Heinzel, A. Materials for Fuel-Cell Technologies. Nature 2001, 414, 345-352.

8. Mahato, N.; Banerjee, A.; Gupta, A.; Omar, S.; Balani, K. Progress in Material Selection for Solid Oxide Fuel Cell Technology: A Review. Prog. Mater Sci. 2015, 72, 141-337.

9. $\quad$ Escorihuela, J.; Narducci, R.; Compañ, V.; Costantino, F. Proton Conductivity of Composite Polyelectrolyte Membranes with Metal-Organic Frameworks for Fuel Cell Applications. Adv. Mater. Interfaces 2019, 6, 1801146-1801146. 
10. Bao, S. S.; Shimizu, G. K. H.; Zheng, L. M. Proton Conductive Metal Phosphonate Frameworks. Coord. Chem. Rev. 2019, 378, 577-594.

11. Umeyama, D.; Funnell, N. P.; Cliffe, M. J.; Hill, J. A.; Goodwin, A. L.; Hijikata, Y.; Itakura, T.; Okubo, T.; Horike, S.; Kitagawa, S. Glass Formation via Structural Fragmentation of a 2D Coordination Network. Chem. Commun. 2015, 51, 12728-12731.

12. Bennett, T. D.; Yue, Y.; Li, P.; Qiao, A.; Tao, H.; Greaves, N. G.; Richards, T.; Lampronti, G. I.; Redfern, S. A.; Blanc, F.; Farha, O. K.; Hupp, J. T.; Cheetham, A. K.; Keen, D. A. Melt-Quenched Glasses of Metal-Organic Frameworks. J. Am. Chem. Soc. 2016, 138, 3484-3492.

13. Bennett, T. D.; Horike, S. Liquid, Glass and Amorphous Solid States of Coordination Polymers and Metal-Organic Frameworks. Nat. Rev. Mater. 2018, 3, 431-440.

14. Qiao, A.; Bennett, T. D.; Tao, H.; Krajnc, A.; Mali, G.; Doherty, C. M.; Thornton, A. W.;

Mauro, J. C.; Greaves, G. N.; Yue, Y. A Metal-Organic Framework with Ultrahigh Glass-Forming Ability. Sci. $A d v . \mathbf{2 0 1 8}, 4$, eaao6827.

15. Horike, S.; Nagarkar, S. S.; Ogawa, T.; Kitagawa, S. New Dimension of Coordination Polymers and Metal-Organic Frameworks toward Functional Glasses and Liquids. Angew. Chem. Int. Ed. 2019. doi.org/10.1002/anie.201911384

16. Horike, S.; Chen, W.; Itakura, T.; Inukai, M.; Umeyama, D.; Asakura, H.; Kitagawa, S. Orderto-Disorder Structural Transformation of a Coordination Polymer and Its Influence on Proton Conduction. Chem. Commun. 2014, 50, 10241-10243.

17. Inukai, M.; Horike, S.; Itakura, T.; Shinozaki, R.; Ogiwara, N.; Umeyama, D.; Nagarkar, S. S.; Nishiyama, Y.; Malon, M.; Hayashi, A.; Ohhara, T.; Kiyanagi, R.; Kitagawa, S. Encapsulating Mobile Proton Carriers into Structural Defects in Coordination Polymer Crystals: High Anhydrous Proton Conduction and Fuel Cell Application. J. Am. Chem. Soc. 2016, 138, 8505-8511.

18. Chen, W.; Horike, S.; Umeyama, D.; Ogiwara, N.; Itakura, T.; Tassel, C.; Goto, Y.; Kageyama, H.; Kitagawa, S. Glass Formation of a Coordination Polymer Crystal for Enhanced Proton Conductivity and Material Flexibility. Angew. Chem. Int. Ed. 2016, 55, 5195-5200.

19. Umeyama, D.; Horike, S.; Inukai, M.; Itakura, T.; Kitagawa, S. Reversible Solid-to-Liquid Phase Transition of Coordination Polymer Crystals. J. Am. Chem. Soc. 2015, 137, 864-870.

20. Nagarkar, S. S.; Kurasho, H.; Duong, N. T.; Nishiyama, Y.; Kitagawa, S.; Horike, S. Crystal Melting and Glass Formation in Copper Thiocyanate Based Coordination Polymers. Chem. Commun. 2019, 55, 5455-5458. 
21. Frentzel-Beyme, L.; Kloss, M.; Kolodzeiski, P.; Pallach, R.; Henke, S. Meltable Mixed-Linker Zeolitic Imidazolate Frameworks and Their Microporous Glasses: From Melting Point Engineering to Selective Hydrocarbon Sorption. J. Am. Chem. Soc. 2019, 141, 12362-12371.

22. Ramaswamy, P.; Wong, N. E.; Shimizu, G. K. MOFs as Proton Conductors--Challenges and Opportunities. Chem. Soc. Rev. 2014, 43, 5913-5932.

23. Greaves, T. L.; Drummond, C. J. Protic Ionic Liquids: Properties and Applications. Chem. Rev. 2008, 108, 206-237.

24. Greaves, T. L.; Drummond, C. J. Protic Ionic Liquids: Evolving Structure-Property Relationships and Expanding Applications. Chem. Rev. 2015, 115, 11379-11448.

25. Nakamoto, H.; Watanabe, M. Brønsted Acid-Base Ionic Liquids for Fuel Cell Electrolytes. Chem. Commun. 2007, 2539-2541.

26. Yoshizawa, M.; Xu, W.; Angell, C. A. Ionic Liquids by Proton Transfer: Vapor Pressure, Conductivity, and the Relevance of $\Delta \mathrm{pKa}$ from Aqueous Solutions. J. Am. Chem. Soc. 2003, 125, 15411-15419.

27. Belieres, J. P.; Angell, C. A. Protic Ionic Liquids: Preparation, Characterization, and Proton Free Energy Level Representation. J. Phys. Chem. B 2007, 111, 4926-4937.

28. Armand, M.; Endres, F.; MacFarlane, D. R.; Ohno, H.; Scrosati, B. Ionic-Liquid Materials for the Electrochemical Challenges of the Future. Nat. Mater. 2009, 8, 621-629.

29. Lee, S. Y.; Ogawa, A.; Kanno, M.; Nakamoto, H.; Yasuda, T.; Watanabe, M. Nonhumidified Intermediate Temperature Fuel Cells Using Protic Ionic Liquids. J. Am. Chem. Soc. 2010, 132, 9764-9773.

30. Yasuda, T.; Watanabe, M. Protic Ionic Liquids: Fuel Cell Applications. MRS Bull. 2013, 38, 560-566.

31. Watanabe, M.; Thomas, M. L.; Zhang, S.; Ueno, K.; Yasuda, T.; Dokko, K. Application of Ionic Liquids to Energy Storage and Conversion Materials and Devices. Chem. Rev. 2017, 117, 7190-7239.

32. Rosli, R. E.; Sulong, A. B.; Daud, W. R. W.; Zullzifley, M. A.; Husaini, T.; Rosli, M. I.; Majlan, E. H.; Haque, M. A. A Review of High-Temperature Proton Exchange Membrane Fuel Cell (HTPEMFC) System. Int. J. Hydrogen Energy 2017, 42, 9293-9314.

33. Widmer, R. N.; Lampronti, G. I.; Anzellini, S.; Gaillac, R.; Farsang, S.; Zhou, C.; Belenguer, A. M.; Wilson, C. W.; Palmer, H.; Kleppe, A. K.; Wharmby, M. T.; Yu, X.; Cohen, S. M.; Telfer, S. G.; Redfern, S. A. T.; Coudert, F. X.; MacLeod, S. G.; Bennett, T. D. Pressure Promoted Low-Temperature Melting of Metal-Organic Frameworks. Nat. Mater. 2019, 18, 370-376.

34. Suzuya, K.; Itoh, K.; Kajinami, A.; Loong, C. K. The Structure of Binary Zinc Phosphate Glasses. J. Non-Cryst. Solids 2004, 345, 80-87. 
35. Hoppe, U.; Dimitriev, Y.; Jovari, P. Structure of Zinc Phosphate Glasses of 75 and 80 Mole\% ZnO Content Studied by X-Ray Diffraction and Reverse Monte Carlo Simulations. Zeitschrift Fur Naturforschung Section a-a Journal of Physical Sciences 2005, 60, 517-526.

36. Onodera, Y.; Kohara, S.; Masai, H.; Koreeda, A.; Okamura, S.; Ohkubo, T. Formation of Metallic Cation-Oxygen Network for Anomalous Thermal Expansion Coefficients in Binary Phosphate Glass. Nat. Commun. 2017, 8, 15449.

37. Miran, M. S.; Kinoshita, H.; Yasuda, T.; Susan, M. A.; Watanabe, M. Physicochemical Properties Determined by $\Delta \mathrm{pK}$ a for Protic Ionic Liquids Based on an Organic Super-Strong Base with Various Brønsted Acids. Phys. Chem. Chem. Phys. 2012, 14, 5178-5186.

38. Brow, R. K.; Tallant, D. R.; Myers, S. T.; Phifer, C. C. The Short-Range Structure of Zinc Polyphosphate Glass. J. Non-Cryst. Solids 1995, 191, 45-55.

39. Wiench, J. W.; Pruski, M.; Tischendorf, B.; Otaigbe, J. U.; Sales, B. C. Structural Studies of Zinc Polyphosphate Glasses by Nuclear Magnetic Resonance. J. Non-Cryst. Solids 2000, 263, 101-110.

40. Walter, G.; Hoppe, U.; Vogel, J.; Carl, G.; Hartmann, P. The Structure of Zinc Polyphosphate Glass Studied by Diffraction Methods and ${ }^{31}$ P NMR. J. Non-Cryst. Solids 2004, 333, 252-262.

41. Shelby, J. E. Introduction to Glass Science and Technology: 2nd Edition The Royal Society of Chemistry, 2005.

42. Zou, Y.; Xu, H.; Wu, G.; Jiang, Z.; Chen, S.; Huang, Y.; Huang, W.; Wei, X. Structural Analysis of $[\mathrm{ChCl}]_{\mathrm{M}}\left[\mathrm{ZnCl}_{2}\right]_{\mathrm{N}}$ Ionic Liquid by X-Ray Absorption Fine Structure Spectroscopy. J. Phys. Chem. B 2009, 113, 2066-2070.

43. D'Angelo, P.; Zitolo, A.; Ceccacci, F.; Caminiti, R.; Aquilanti, G. Structural Characterization of Zinc(II) Chloride in Aqueous Solution and in the Protic Ionic Liquid Ethyl Ammonium Nitrate by X-Ray Absorption Spectroscopy. J. Chem. Phys. 2011, 135, 154509.

44. Sessa, F.; Migliorati, V.; Serva, A.; Lapi, A.; Aquilanti, G.; Mancini, G.; D'Angelo, P. On the Coordination of $\mathrm{Zn}^{2+}$ Ion in $\mathrm{Tf}_{2} \mathrm{~N}^{-}$Based Ionic Liquids: Structural and Dynamic Properties Depending on the Nature of the Organic Cation. Phys. Chem. Chem. Phys. 2018, 20, 2662-2675.

45. Herschke, L.; Enkelmann, V.; Lieberwirth, I.; Wegner, G. The Role of Hydrogen Bonding in the Crystal Structures of Zinc Phosphate Hydrates. Chemistry 2004, 10, 2795-2803.

46. Barsoukov, E. Impedance Spectroscopy Theory, Experiment, and Applications Second Edition Preface. Impedance Spectroscopy: Theory, Experiment, and Applications, 2nd Edition 2005, Xii-+.

47. Brigouleix, C.; Anouti, M.; Jacquemin, J.; Caillon-Caravanier, M.; Galiano, H.; Lemordant, D. Physicochemical Characterization of Morpholinium Cation Based Protic Ionic Liquids Used as Electrolytes. $J$. Phys. Chem. B 2010, 114, 1757-1766. 
48. Vogel, H. Das Temperaturabhaengigkeitsgesetz Der Viskositaet Von Fluessigkeiten. Phys. Z. 1921, 22, 645-656.

49. Fulcher, G. S. Analysis of Recent Measurements of the Viscosity of Glasses. J. Am. Ceram. Soc. 1925, 8, 339-355.

50. Susan, M. A.; Kaneko, T.; Noda, A.; Watanabe, M. Ion Gels Prepared by in Situ Radical Polymerization of Vinyl Monomers in an Ionic Liquid and Their Characterization as Polymer Electrolytes. J. Am. Chem. Soc. 2005, 127, 4976-4983.

51. Galiński, M.; Lewandowski, A.; Stępniak, I. Ionic Liquids as Electrolytes. Electrochim. Acta 2006, 51, 5567-5580.

52. Noda, A.; Susan, M. A. B. H.; Kudo, K.; Mitsushima, S.; Hayamizu, K.; Watanabe, M. Brønsted Acid-Base Ionic Liquids as Proton-Conducting Nonaqueous Electrolytes. J. Phys. Chem. B 2003, 107, 40244033 .

53. Nakamoto, H.; Noda, A.; Hayamizu, K.; Hayashi, S.; Hamaguchi, H.-o.; Watanabe, M. ProtonConducting Properties of a Brønsted Acid-Base Ionic Liquid and Ionic Melts Consisting of Bis(Trifluoromethanesulfonyl)Imide and Benzimidazole for Fuel Cell Electrolytes. J. Phys. Chem. C 2007, 111, 1541-1548.

54. Lee, S. Y.; Yasuda, T.; Watanabe, M. Fabrication of Protic Ionic Liquid/Sulfonated Polyimide Composite Membranes for Non-Humidified Fuel Cells. J. Power Sources 2010, 195, 5909-5914.

55. Norby, T. Emf Method Determination of Conductivity Contributions from Protons and Other Foreign Ions in Oxides. Solid State Ionics 1988, 28, 1586-1591.

56. U. S. Department of Energy, Fuel Cell Handbook (Seventh Edition). 2016.

57. Haque, M. A.; Sulong, A. B.; Loh, K. S.; Majlan, E. H.; Husaini, T.; Rosli, R. E. Acid Doped Polybenzimidazoles Based Membrane Electrode Assembly for High Temperature Proton Exchange Membrane Fuel Cell: A Review. Int. J. Hydrogen Energy 2017, 42, 9156-9179.

58. Gui, D.; Dai, X.; Tao, Z.; Zheng, T.; Wang, X.; Silver, M. A.; Shu, J.; Chen, L.; Wang, Y.; Zhang, T.; Xie, J.; Zou, L.; Xia, Y.; Zhang, J.; Zhang, J.; Zhao, L.; Diwu, J.; Zhou, R.;

Chai, Z.; Wang, S. Unique Proton Transportation Pathway in a Robust Inorganic Coordination Polymer Leading to Intrinsically High and Sustainable Anhydrous Proton Conductivity. J. Am. Chem. Soc. 2018, 140, 6146-6155. 59. Aiyappa, H. B.; Saha, S.; Wadge, P.; Banerjee, R.; Kurungot, S. Fe(III) Phytate Metallogel as a Prototype Anhydrous, Intermediate Temperature Proton Conductor. Chem. Sci. 2015, 6, 603-607.

60. Zarrin, H.; Higgins, D.; Jun, Y.; Chen, Z.; Fowler, M. Functionalized Graphene Oxide Nanocomposite Membrane for Low Humidity and High Temperature Proton Exchange Membrane Fuel Cells. $J$. Phys. Chem. C 2011, 115, 20774-20781. 
61. Anouti, M.; Caillon-Caravanier, M.; Dridi, Y.; Galiano, H.; Lemordant, D. Synthesis and Characterization of New Pyrrolidinium Based Protic Ionic Liquids. Good and Superionic Liquids. J. Phys. Chem. B 2008, 112, 13335-13343.

62. He, Q.; Kelliher, M.; Bahring, S.; Lynch, V. M.; Sessler, J. L. A Bis-Calix[4]Pyrrole Enzyme Mimic That Constrains Two Oxoanions in Close Proximity. J. Am. Chem. Soc. 2017, 139, 7140-7143.

63. Fatila, E. M.; Pink, M.; Twum, E. B.; Karty, J. A.; Flood, A. H. Phosphate-Phosphate Oligomerization Drives Higher Order Co-Assemblies with Stacks of Cyanostar Macrocycles. Chem. Sci. 2018, 9 , 2863-2872.

64. Marzari, N.; Vanderbilt, D. Maximally Localized Generalized Wannier Functions for Composite Energy Bands. Physical Review B 1997, 56, 12847-12865.

65. Faber, T. E.; Ziman, J. M. A Theory of the Electrical Properties of Liquid Metals. Philosophical Magazine 1965, 11, 153-173.

66. Kohara, S.; Itou, M.; Suzuya, K.; Inamura, Y.; Sakurai, Y.; Ohishi, Y.; Takata, M. Structural Studies of Disordered Materials Using High-Energy X-Ray Diffraction from Ambient to Extreme Conditions. Journal of Physics-Condensed Matter 2007, 19.

67. Lorch, E. Neutron Diffraction by Germania, Silica and Radiation-Damaged Silica Glasses. Journal of Physics C: Solid State Physics 1969, 2, 229-237.

68. Gereben, O.; Jovari, P.; Temleitner, L.; Pusztai, L. A New Version of the RMC++ Reverse Monte Carlo Programme, Aimed at Investigating the Structure of Covalent Glasses. Journal of Optoelectronics and Advanced Materials 2007, 9, 3021-3027.

69. Ankudinov, A. L.; Ravel, B.; Rehr, J. J.; Conradson, S. D. Real-Space Multiple-Scattering Calculation and Interpretation of X-Ray-Absorption near-Edge Structure. Physical Review B 1998, 58, 75657576. 